\section{Hjemmebesøk gir bedre helse hos nyfødte i u-land}

En studie fra rurale områder i Bangladesh viser at besøk av helsearbeidere i hjemmet kan bedre nyfødtes helse og gi $ø$ kt overlevelse i utviklingsland (1).

Helsearbeiderne, kvinner som hadde fullført grunnskolen, fikk 36 dagers opplæring ved et lokalt sykehus. De evaluerte amming og symptomer på sykdom ved fødselen og to, fem og åtte dager etter $f ø d s e l e n$ ved hjelp av en algoritme. Nyfødte med symptomer på alvorlig sykdom ble henvist til det lokale sykehuset.

Helsen til 395 nyfødte ble evaluert. Innen 12 timer ble de nyfødte også undersøkt av lege, og disse evalueringene ble brukt til å validere helsearbeidernes identifisering av symptomer. Helsearbeiderne identifiserte alvorlig sykdom med en sensitivitet på $73 \%$ og en spesifisitet på $98 \%$. Positiv og negativ prediktiv verdi var henholdsvis $57 \%$ og $99 \%$.

Liknende resultater når det gjelder eldre barn er vist tidligere, men det finnes lite dokumentasjon på nøyaktigheten av helsearbeideres vurdering av barn i første leveuke. Fire millioner nyfødte dør hvert år, noe som utgjør $38 \%$ av alle dødsfall hos barn under fem år. $75 \%$ av nyfødtdødsfallene finner sted i løpet av første leveuke.

- Helsearbeiderne identifiserte med høy validitet barna med alvorlig sykdom som trengte sykehusbehandling. Bekreftelse og behandling av sykdom i hjemmet, inkludert hensvisning av alvorlig syke barn til sykehus, er en lovende strategi for å bedre nyfødtes helse i utviklingsland, sier førsteforfatter Gary L. Darmstadt.

\section{Oda Riska}

oriska@hotmail.com

Tidsskriftet

\section{Litteratur}

1. Darmstadt GL, Baqui AH et al. Validation of community health workers' assessment of neonatal illness in rural Bangladesh. Bull World Health Organ 2009; 87: $12-9$

\section{Epilepsikampanje i Kina viser positive resultater}

\author{
Epilepsi er den vanligste alvorlige nevrologiske sykdommen i verden \\ og affiserer rundt 50 millioner mennesker. Inntil $90 \%$ av epileptikere \\ i u-land får ingen eller kun dårlig behandling. En kampanje på lands- \\ bygda i Kina for å øke kunnskap om og behandling av epilepsi har vist \\ noen positive resultater.
}

Kampanjen var en del av Verdens helseorganisasjons Global Campaign Against Epilepsy, i samarbeid med Kinas helsedepartement (1). Kampanjen vektla informasjon om årsaker og behandling av epilepsi i massemediene, undervisning og gruppediskusjoner for pasienter og deres familier samt informasjon til lærere og undervisning for leger. Pasienter ble oppfordret til å oppsøke helsevesenet for å få gratis vurdering og eventuelt behandling. Målet var å øke andelen epileptikere som fikk god behandling, øke kunnskap om epilepsi i samfunnet og redusere stigma rundt sykdommen.

Epidemiologiske spørreundersøkelser ble utført før (i 2000) og etter (i 2004) kampanjen. Det var ingen signifikant forskjell i prevalens av aktiv epilepsi ved de to tidspunktene, men det var en vesentlig forskjell $i$ andelen pasienter med aktiv epilepsi som fikk behandling. I 2000 fikk kun 37,4 \% behandling i uken før spørreundersøkelsen, mens dette hadde økt til 50,2\% etter kampanjen.

- Resultatene av denne studien tyder på at kampanjen var effektiv, reduserte andelen epileptikere som ikke får behandling, og er gjennomførbar i landlige Kina, sier førsteforfatter, Wenzhi Wang.

Det er mye stigmatisering rundt epilepsi i Kina, som i mange u-land. Rundt halvparten av Kinas befolkning mener at epileptikere ikke burde være $\mathrm{i}$ arbeidslivet.

- Epilepsi er ofte ikke sett på som en «vanlig» sykdom, men som galskap. Derfor er det veldig viktig å øke kunnskap om epilepsi og spre informasjon i samfunnet, sier Wang.

- Studien var av verdi fordi den økte lokalsamfunnets kunnskap om epilepsi og om at sykdommen kan behandles, konkluderer Wang.

\section{Oda Riska}

oriska@hotmail.com

Tidsskriftet

\section{Litteratur}

Wang W, Wu J, Dai X et al. Global campaign against epilepsy: assessment of a demonstration project in rural China. Bull World Health Organ 2008; 86: 964-9.

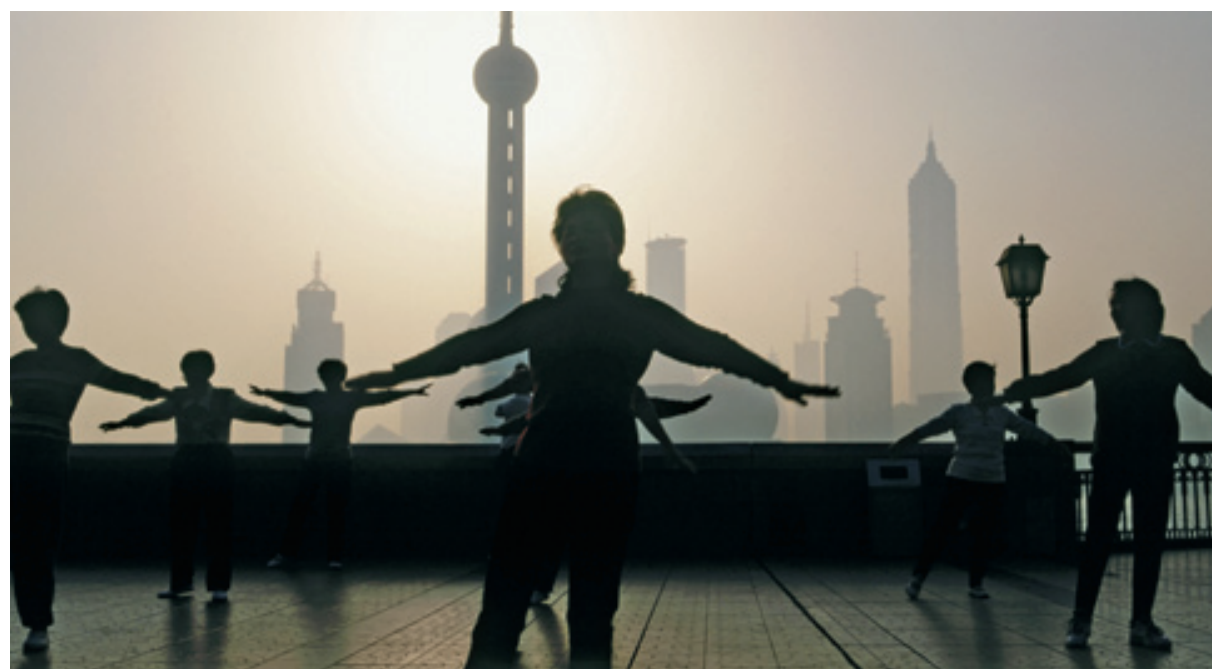

Halvparten av Kinas befolkning mener epileptikere ikke burde være i arbeidslivet. Illustrasjonsfoto AGE/GV-Press/NordicPhotos 